\title{
Jurnal Ilmiah Informatika (JIF)
}

\author{
｜ＩSSN (Print) 2337-8379 ｜ＩSSN (Online) 2615-1049 |
}

Jurnal online di akses di http://ejournal.upbatam.ac.id/index.php/jif

\section{Penerapan Metode Weighted Product Untuk Penentuan Penerima Bansos Kepada Masyarakat Terdampak Covid-19}

\author{
Dian Permata Sari \\ ${ }^{a}$ STMIK Jayanusa, Jl. Olo Ladang No.1, Padang 25116, Indonesia
}

\section{INFORMASI ARTIKEL}

Sejarah Artikel:

Diterima Redaksi: 15 Des 2020

Revisi Akhir: 22 Feb 2021

Diterbitkan Online: 30 April 2021

\begin{tabular}{l} 
KATA KUNCI \\
\hline Sistem pendukung keputusan \\
Bantuan social \\
Covid-19 \\
Weighted Product
\end{tabular}

\section{KORESPONDENSI}

E-mail: langitbiru621@gmail.com

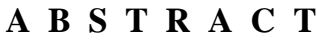

Since Covid 19 attacked Indonesia, almost all sectors have been affected. In the education sector, which requires students to study from home (online), in the economic sector the poverty rate is getting higher, many workers have been laid off and some are sent home. The face of the Indonesian economy has become a mess. One of the ways for the government to reduce the impact of the COVID-19 pandemic is to provide social assistance to the community. However, in distributing aid, the distributors are often constrained in prioritizing the recipient community. The mechanisms for distributing aid are complicated and often not well targeted due to inappropriate criteria for beneficiaries and inaccurate / inaccurate data. So that not a few people protested because they did not receive assistance even though they were also affected by the Covid 19 pandemic. The decision support system using the weighted product method was considered capable of finding the highest priority for beneficiaries based on predetermined criteria, namely employment status, home status, domicile, dependents. and income per month. The final result is a rating of vactor $V$ where the alternative which has the highest value has the highest priority to receive assistance.
\end{abstract}

\section{PENDAHULUAN}

Saat ini dunia dihebohkan dengan munculnya virus baru yang diberi nama virus corona. Hampir seluruh negara di dunia termasuk Indonesia mengalami serangan virus ini. Corona virus merupakan keluarga besar virus yang menyebabkan penyakit pada manusia dan hewan. Pada manusia biasanya menyebabkan penyakit infeksi saluran pernapasan, mulai flu biasa hingga penyakit yang serius seperti Middle East Respiratory Syndrome(MERS) dan Sindrom Pernafasan Akut Berat/Severe Acute Respiratory Syndrome(SARS).[1]

Warga Negara Indonesia terkonfirmasi pertama sekali positif covid 19 yaitu pada awal maret 2020. Sejak itu, berbagai upaya penanggulangan dilakukan pemerintah untuk meredam dampak dari pandemi Covid-19 di berbagai sektor. Hampir seluruh sektor terdampak, tak hanya kesehatan. Sektor ekonomi juga mengalami dampak serius akibat pandemi virus corona.[2] Karena pemerintah melakukan pembatasan sosial berskala besar (PSBB) untuk memutus mata rantai penyebaran virus ini. Sehingga banyak kegiatan perekonomian yang lumpuh, banyaknya karyawan yang dirumahkan sampai dengan PHK besar-besaran.

Dian Permata Sari
Salah satu upaya pemerintah dalam menyikapi dampak pandemi covid 19 adalaha dengan memberikan bantuan sosial khusus untuk masyarakat golongan menengah ke bawah. Bantuan tersebut, ada yang terdiri dari bantuan non tunai berupa paket sembako dan bantuan tunai berupa uang. Penentuan siapa yang berhak menerima bantuan perlu dilakukan dengan sangat hatihati agar bantuan yang diberikan tepat sasaran dan memenuhi azas keadilan bagi semua.[3]

Warga Jorong Batang Piarau Nagari Kp. Pinang Kec. Lubuk Basung Kabupaten Agam merupakan salah satu yang akan menerima bantuan dana sosial dampak pandemi covid 19 dari pemerintah. Dalam penyaluran bantuan sosial sering kali terjadi kesalahan-kesalahan yang dihadapi dilapangan mulai dari pendataan warga, ketepatan target sampai kepada pendistribusian bantuan.

Penerimaan bantuan dari nagari yang di terima oleh jorong tidak mencukupi untuk membatu semua warga yang mendaftarkan diri terdampak secara ekonomi karena pandemi Covid-19, sehingga perlu ditetapkan prioritas warga yang benar benar membutuhkan untuk diberi bantuan sosial, kemudian belum adanya kriteria dan pembobotan yang tepat dari masing masing 
kriteria dalam penentuan penerima bantuan sosial pada saat pandemi Covid 19, sehingga tidak tepat sasaran yang menimbulkan protes dari warga yang seharusnya mendapatkan bantuan tetapi mereka tidak mendapatkan bantuan tersebut, begitupun sebaliknya. Mekanime penyaluran bantuan belum menggunakan metode yang tepat dalam menentukan penerima bantuan sosial pada saat pandemi covid-19, sehingga tingginya subyektifitas dalam penentuan penerima bantuan sosial tersebut.[3]

Penelitian-penelitian sebelumnya terkait dengan metode pendukung keputusan dalam menentukan penerima bantuan telah banyak dilakukan. Diantaranya penerapan metode analytical hierarchy process (AHP) dan simple additive weighting (SAW) untuk penentuan penerima bantuan sosial pandemi covid-19. Penelitian ini menghasilkan nilai bobot kriteria Status pekerjaan kepala keluarga sebesar 0,425, Status pekerjaan istri sebesar 0,166, Status rumah sebesar 0,094, jumlah tanggungan sebesar 0,056 dan KTP sebesar 0,259 dengan nilai consistency ratio sebesar 0,09.[3]

Penelitian lainnya yaitu implementasi metode weighted product untuk penentuan mustahiq zakat. Dalam perhitungan Weighted Product digunakan beberapa kriteria acuan untuk seluruh alternatif dengan melakukan perkalian untuk menghubungkan rating atribut, di mana rating setiap atribut harus dipangkatkan dahulu dengan bobot atribut yang bersangkutan. Hasil akhir perhitungan Weighted Product adalah nilai vektor V, di mana alternatif yang mendapat nilai $\mathrm{V}$ tertinggi merupakan alternatif yang diprioritaskan sebagai penerima zakat.[4]

Penelitian lain yang menerapkan metode weighted product adalah penerapan metode weighted product untuk menentukan penerima bantuan beras masyarakat miskin (raskin). Hasil dari penelitian ini adalah penerapan metode Weighted Product untuk menentukan penerima bantuan raskin di Kelurahan Air Putih. Penelitian yang dilakukan dengan mencari bobot untuk setiap atribut, kemudian dilakukan proses peringkat yang akan menentukan alternatif optimal, calon penerima raskin. Berdasarkan pengujian yang dilakukan, sistem yang diciptakan untuk memberikan hasil yang baik sesuai dengan perhitungan yang digunakan, membantu mempercepat pemilihan penerima Raskin, dan sistem juga dapat mengurangi kesalahan dalam menentukan penerima Raskin. [5]Penelitian yang dilakukan oleh Deny Wiria Nugraha, dkk dengan hasil penelitian yaitu penyaluran dana bantuan langsung lebih cepat dan proposisi.[6]

Dalam penelitian ini akan diimplementasikan salah satu metode dalam pengambilan keputusan yaitu Weighted Product (WP) untuk membantu kepala jorong dalam penyaluran bantuan agar tepat sasaran dan menghindari adanya faktor subjektifitas dalam penyaluran bantuan. Adapun kriteria penerima bantuan ini adalah: status pekerjaan, status rumah, domisili, tanggunga, dan penghasilan per bulan.

\section{TINJAUAN PUSTAKA}

Pengertian system pendukung keputusan

System adalah kumpulan dari obyek-obyek seperti orang, resource, konsep, dan prosedur yang ditujukan untuk melakukan

6 Dian Permata Sari fungsi tertentu atau untuk memenuhi suatu tujuan. Kemudian system juga merupakan kumpulan dari komponen yang berinteraksi bersama-sama secara kolektif untuk melaksanakan tujuan.[7]

Pengambilan keputusan merupakan hal yang penting bagi suatu bisnis dan organisasi. Dengan memilih keputusan yang tepat, suatu bisnis dan/atau organisasi dapat memecahkan masalah yang dihadapi dengan

memanfaatkan sumber daya yang dimiliki dengan efisien supaya bisnis dan/atau organisasi mampu mencapai tujuannya.[7]

\section{METODOLOGI}

\subsection{Tahap Pengumpulan Data}

Metode pengumpulan data seperti wawancara kepada pihakpihak yang terlibat dalam pendistribusian bantuan). Studi kepustakaan merupakan cara pengumpulan data dengan mempelajari artikel - artikel, paket modul dan panduan, buku buku pedoman, jurnal-jurnal dan segala kepustakaan lainnya yang dianggap perlu dan mendukung Analisa Data. Pada tahap ini penulis melakukan analisa terhadap data-data yang telah diperoleh sebelumnya.

Kerangka kerja merupakan tahapan-tahapan yang akan dilakukan dalam rangka penyelesaian masalah yang akan dibahas. Adapun tahapan yang penulis lakukan pada penelitian ini dapat dilihat pada gambar 1 di bawah ini:

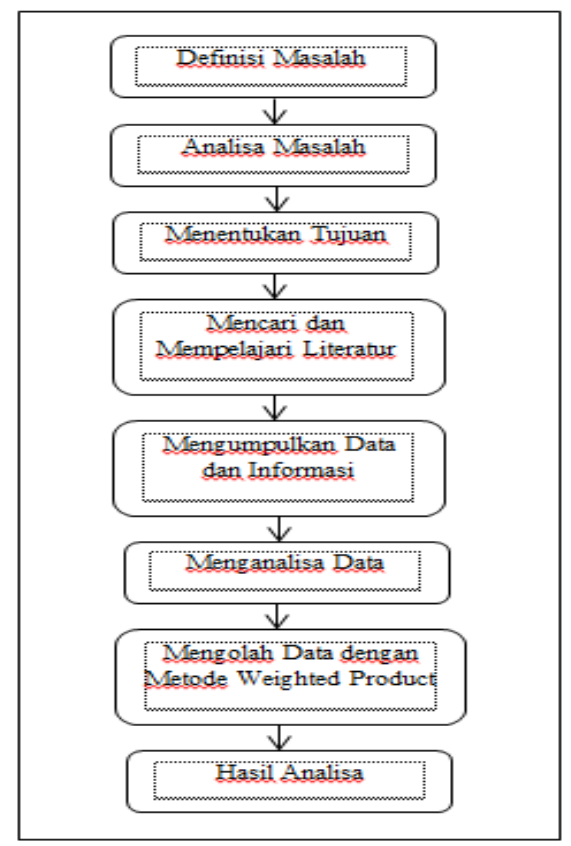

Gambar 1. Urutan Peneltian

1. Definisi Masalah

Pada penelitian ini ruang lingkup permasalahan ditekankan kepada masyarakat penerima bansos, apaapa saja yang menjadi syarat untuk seseorang layak menerima bansos

2. Analisa masalah

Setelah mendefiniskan masalah langkah selanjutnya proses analisa masalah. Dengan menganalisa permasalahan yang telah ditentukan tersebut, maka

Penerapan Metode Weighted Product 
diharapkan masalah tersebut dapat dipahami dengan baik.

3. Menentukan Tujuan

Berdasarkan pemahaman dari masalah, msks ditentukan tujuan yang akan dicapai dari penelitian ini. Pada tujuan ini pengambilan suatu keputusan prioritas utama yang berhak mendpatkan bantuan sehingga bantuan yang diberikan tepat sasaran.

4. Mencari dan Mempelajari Literatur Untuk mencapai tujuan, maka dipelajari beberapa literature yang dapat digunakan. Kemudian literaturliteratur yang dipelajari tersebut diseleksi untuk dapat ditentukan literaur mana yang akan digunakan dalam penelitian ini. Seumber literature diperoleh dari bukubuku dan jurnal-jurnal di internet.

5. Mengumpulkan Data dan Informasi

Mengumpulkan data untuk melakukan analisis padametode Weighted Product. Semakin banyak data diperoleh, semakin baik dalam meyelesaikan permasalahan. Mengumpulkan data yang akurat dan membagi data tersebut ke dalam metode yang sudah ditentukan. Pembagian kriteria dan karakteristik digunakan untuk mempermudah dalam pengelompokan data pengambilan keputusan

6. Menganalisa Data

Setelah data dikumpulkan, maka akan dilakukan analisa data untuk menyesuaikan kegiatan data yang akan diolah pada metode Weighted Product.

7. Mengolah Data dengan Metode Weighted Product Pada pengolahan data akan dilakukan beberapa kegiatan yaitu normalisasi atau perbaikan bobot, menentukan nilai vector (s), mengitung vector $\mathrm{v}$ hingga terkahir melakukan perangkingan nilai dari hasil vector $\mathrm{v}$.

\subsection{Weighted Product}

Metode Weighted product merupakan bagian dari analisis multi kriteria keputusan (multi criteria decision analysis/ MCDA) yang sangat terkenal[8]. Metode WP mirip dengan Metode Weighted Sum (WS), hanya saja metode WP terdapat perkalian dalam perhitungan matematikanya. Metode WP juga disebut analisis berdimensi karena struktur matematikanya menghilangkan satuan ukuran. [9]Weighted Product menggunakan teknik perkalian untuk menghubungkan rating atribut, di mana rating tiap atribut harus di pangkatkan terlebih dahulu dengan atribut bobot yang bersangkutan. Langkahlangkah yang dilakukan dalam penyelesaian masalah menggunakan metode Weighted Product. [10]

a. Normalisasi atau Perbaikan Bobot.

$$
W J=W j / \sum W j
$$

Keterangan:

WJ: Nilai Perbaikan Bobot

Wj: Nilai Bobot

$\sum W j$ : Total Penjumlahan Nilai Bobot

b. Menentukan Nilai Vektor (s)

$S_{i}=\prod_{j=1}^{n} 1 X_{i j} W_{j}$

Keterangan:

Si: nilai preferensi alternatif ke $\mathrm{i}=(1,2,3 \ldots)$
$\Pi$ : produk perkalian

Xij: nilai kriteria ke-j pada alternatif ke-i

Wj: nilai bobot pada kriteria ke-j

n: banyaknya kriteria

c. Menentukan Nilai Vektor

$$
V i=\frac{\prod_{j}^{n}=1 X_{i j} W_{j}}{\prod_{j}^{n}=1\left(X_{j}^{*}\right) W_{j}}
$$

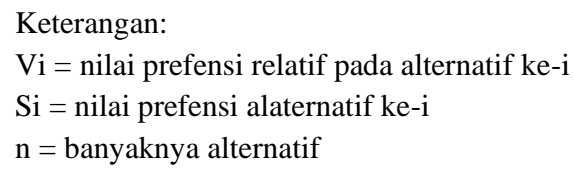

\section{HASIL DAN PEMBAHASAN}

Pada penelitian ini penulis melakukan analisis terhadap kriteriakriteria yang dijadikan penilaian penerima bantuan sosial. Ada lima kriteria yang digunakan yaitu status pekerjaan, status rumah, domisili, tanggungan dan penghasilan per bulan.

4.1 Menentukan kriteria dan bobot kriteria

Langkah awal yang dilakukan adalah menentukan kriteria dan nilai bobot kriteria yang dijadikan acuan dalam pengambilan keputusan. Masing-masing kriteria memilki bobot yang berbeda.

Tabel 1. Kriteria Dan Bobot Kriteria

\begin{tabular}{|l|l|l|}
\hline Kriteria & Keterangan & Bobot Kriteria \\
\hline C1 & Status pekerjaan & 4 \\
C2 & Status rumah & 5 \\
C3 & Domisili & 3 \\
C4 & Tanggungan & 4 \\
C5 & Penghasilan per bulan & 5 \\
\hline
\end{tabular}

Berikut merupakan kriteria-kriteria yang digunakan dalam penentuan penerima bantuan sosial:

\begin{tabular}{|c|c|c|c|}
\hline No & Kriteria & Sub Kriteria & $\begin{array}{l}\text { Nilai } \\
\text { Skala }\end{array}$ \\
\hline \multirow{5}{*}{1} & \multirow{5}{*}{$\begin{array}{l}\text { Satus } \\
\text { pekerjaan }\end{array}$} & Serabutan & 5 \\
\hline & & PHK & 4 \\
\hline & & Dirumahkan & 3 \\
\hline & & Usaha mandiri & 2 \\
\hline & & Numpang & 5 \\
\hline \multirow{3}{*}{2} & \multirow{3}{*}{ Status rumah } & Kontrak & 4 \\
\hline & & $\begin{array}{l}\text { Tinggal dengan } \\
\text { keluarga }\end{array}$ & 3 \\
\hline & & Milik sendiri & 2 \\
\hline \multirow{3}{*}{3} & \multirow{3}{*}{ Domisili } & Lubuk basung & 5 \\
\hline & & Luar lubuk basung & 4 \\
\hline & & $>4$ orang & 5 \\
\hline \multirow{4}{*}{4} & \multirow{4}{*}{ Tanggungan } & 4 orang & 4 \\
\hline & & 3 orang & 3 \\
\hline & & 2 orang & 2 \\
\hline & & 1 orang & 1 \\
\hline \multirow{5}{*}{5} & \multirow{5}{*}{$\begin{array}{l}\text { Penghasilan } \\
\text { per bulan }\end{array}$} & Tidak tetap & 5 \\
\hline & & $<1.000 .000$ & 4 \\
\hline & & $1.000 .000-2.000 .000$ & 3 \\
\hline & & $2.000 .000-3.000 .000$ & 2 \\
\hline & & $>3.000 .000$ & 1 \\
\hline
\end{tabular}

Tabel 2. Kriteria Penerima Bantuan Sosial 
Pada tabel di atas terdapat lima kriteria[4] penerima bansos yaitu status pekerjaan dangan sub kriteria serabutan, phk, dirumahkan dan usaha mandiri. Kriteria kedua status rumah dengan sub kriteria numpang, kontrak, tinggal dengan keluarga dan milik sendiri, selanjutnya domisili sub kriteria yaitu lubuk basung dan luar lubuk basung, tanggungan sub kriteria nya adalah $>4$ orang, 4orang , 3 orang, 2 orang dan 1 oraang. Terakhir kriteria penghasilan per bulan yaitu tidak tetap, $<1.000 .000,1.000 .000$ $2.000 .000,2.000 .000-3.000 .000$ dan $>3.000 .000$.

4.2 Memasukkan data alternatif penerima bantuan sosial Di bawah ini adalah sampel data alternative penerima bantuan sosial dengan kriteria-kriteria yang telah ditentukan:

Tabel 3. Data Alternatif Penerima Bantuan Sosial

\begin{tabular}{|c|c|c|c|c|c|c|}
\hline $\begin{array}{l}\mathrm{N} \\
\mathbf{o}\end{array}$ & $\begin{array}{l}\text { Alt } \\
\text { ern } \\
\text { atif }\end{array}$ & $\begin{array}{l}\text { Satus } \\
\text { Pekerjaan }\end{array}$ & $\begin{array}{l}\text { Status } \\
\text { Rumah }\end{array}$ & Domisili & $\begin{array}{l}\text { Tanggun } \\
\text { gan }\end{array}$ & $\begin{array}{l}\text { Penghasilan } \\
\text { per Bulan }\end{array}$ \\
\hline 1 & $\mathrm{~A}$ & Serabutan & Kontrak & $\begin{array}{l}\text { Lubuk } \\
\text { basung }\end{array}$ & 3 orang & Tidak tetap \\
\hline 2 & B & Serabutan & Kontrak & $\begin{array}{l}\text { Lubuk } \\
\text { basung }\end{array}$ & 2 orang & Tidak tetap \\
\hline 3 & $\mathrm{C}$ & PHK & Kontrak & $\begin{array}{l}\text { Lubuk } \\
\text { basung }\end{array}$ & 3 orang & $\begin{array}{l}2.000 .000- \\
3.000 .000\end{array}$ \\
\hline 4 & D & Dirumahkan & Kontrak & $\begin{array}{l}\text { Lubuk } \\
\text { basung }\end{array}$ & 4 orang & $\begin{array}{l}2.000 .000- \\
3.000 .000\end{array}$ \\
\hline 5 & E & $\begin{array}{l}\text { Usaha } \\
\text { mandiri }\end{array}$ & $\begin{array}{l}\text { Tinggal } \\
\text { dengan } \\
\text { keluarga }\end{array}$ & $\begin{array}{l}\text { Lubuk } \\
\text { basung }\end{array}$ & 4 orang & $\begin{array}{l}1.000 .000- \\
2.000 .000\end{array}$ \\
\hline 6 & F & PHK & Kontrak & $\begin{array}{l}\text { Luar } \\
\text { lubuk } \\
\text { basung }\end{array}$ & 2 orang & $\begin{array}{l}2.000 .000- \\
3.000 .000\end{array}$ \\
\hline 7 & G & Dirumahkan & $\begin{array}{l}\text { Tinggal } \\
\text { dengan } \\
\text { keluarga }\end{array}$ & $\begin{array}{l}\text { Lubuk } \\
\text { basung }\end{array}$ & 2 orang & $\begin{array}{l}1.000 .000- \\
2.000 .000\end{array}$ \\
\hline 8 & $\mathrm{H}$ & Serabutan & Numpang & $\begin{array}{l}\text { Lubuk } \\
\text { basung }\end{array}$ & 4 orang & Tidak tetap \\
\hline 9 & I & PHK & $\begin{array}{l}\text { Tinggal } \\
\text { dengan } \\
\text { keluarga }\end{array}$ & $\begin{array}{l}\text { Luar } \\
\text { lubuk } \\
\text { basung }\end{array}$ & 4 orang & $\begin{array}{l}2.000 .000- \\
3.000 .000\end{array}$ \\
\hline $\begin{array}{l}1 \\
0\end{array}$ & $\mathrm{~J}$ & PHK & $\begin{array}{l}\text { Milik } \\
\text { sendiri }\end{array}$ & $\begin{array}{l}\text { Lubuk } \\
\text { basung }\end{array}$ & 2 orang & $\begin{array}{l}2.000 .000- \\
3.000 .000\end{array}$ \\
\hline
\end{tabular}

4.3 Merubah nilai kriteria alternatif

Setelah data alternatif dimasukkan kemudian mengubah nilai skala dari masing-masing kriteria alternatif sesuai dengan nilai skala yang sudah ditentukan.

Tabel 4. Perubahan Nilai Skala Kriteria Alternatif

\begin{tabular}{|l|l|l|l|l|l|}
\hline Alternatif & C1 & C2 & C3 & C4 & C5 \\
\hline A & 5 & 4 & 5 & 3 & 5 \\
B & 5 & 4 & 5 & 2 & 5 \\
C & 4 & 4 & 5 & 3 & 2 \\
D & 3 & 4 & 5 & 4 & 2 \\
E & 2 & 3 & 5 & 4 & 3 \\
F & 4 & 4 & 4 & 2 & 2 \\
G & 3 & 3 & 5 & 2 & 3 \\
H & 5 & 5 & 5 & 4 & 5 \\
I & 4 & 3 & 4 & 4 & 2 \\
J & 4 & 2 & 5 & 2 & 2 \\
\hline
\end{tabular}

Data perubahan nilai pada Tabel 4 menghasilkan matriks sebagai berikut;

$\begin{array}{lllll}5 & 4 & 5 & 3 & 5 \\ 5 & 4 & 5 & 2 & 5\end{array}$

$8 \quad$ Dian Permata Sari

$\begin{array}{lllll}4 & 4 & 5 & 3 & 2 \\ 3 & 4 & 5 & 4 & 2 \\ 2 & 3 & 5 & 4 & 3 \\ 4 & 4 & 4 & 2 & 2 \\ 3 & 3 & 5 & 2 & 3 \\ 5 & 5 & 5 & 4 & 5 \\ 4 & 3 & 4 & 4 & 2 \\ 4 & 2 & 5 & 2 & 2\end{array}$

4.4 Menghitung nilai normalisasi bobot

Melakukan proses normalisasi terhadap bobot dengan cara bobot dibagi dengan total keseluruhan bobot.

$\mathrm{W}=(4,5,3,4,5)$

$$
\begin{aligned}
& \mathrm{W} 1=\frac{4}{4+5+3+4+5}=0,1904761905 \\
& \mathrm{~W} 2=\frac{5}{4+5+3+4+5}=0,2380952381 \\
& \mathrm{~W} 3=\frac{3}{4+5+3+4+5}=0,1428571429 \\
& \mathrm{~W} 4=\frac{4}{4+5+3+4+5}=0,1904761905 \\
& \mathrm{~W} 5=\frac{5}{4+5+3+4+5}=0,2380952381 \\
& \sum_{j}^{w}=0,1904761905+0,2380952381+0,1428571429 \\
& +0,1904761905+0,2380952381=1
\end{aligned}
$$

4.5 Menghitung vektor $\mathrm{S}$

Setelah menghitung normalisasi bobot tahap selanjutnya adalah menghitung nilai vektor $\mathrm{S}$.

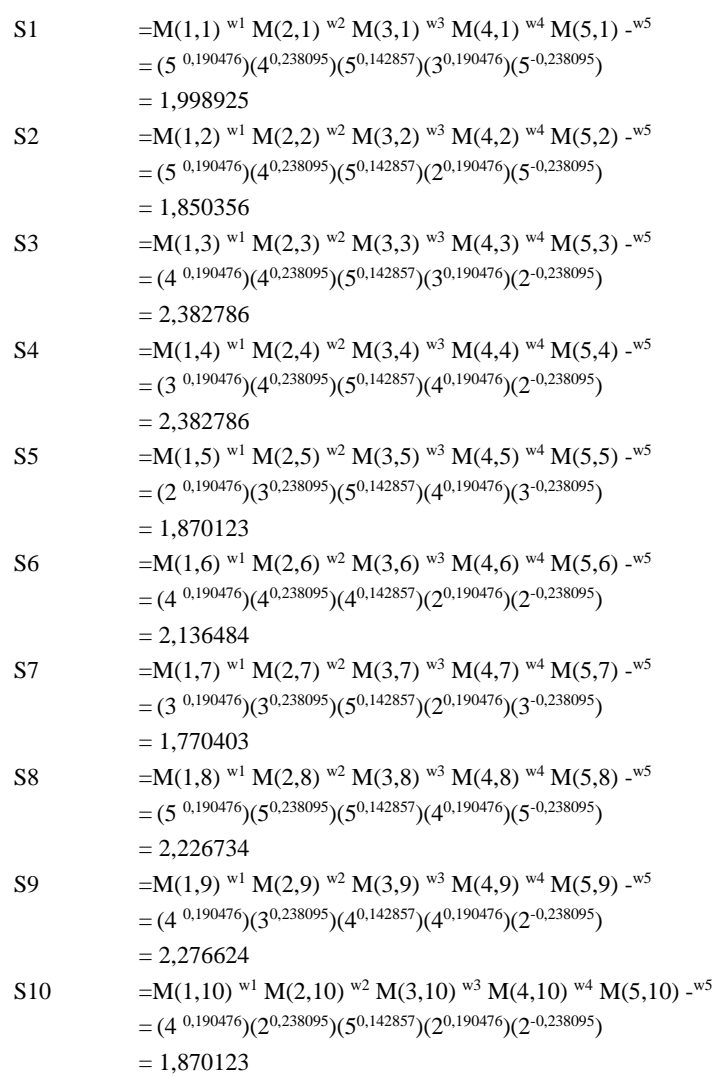

4.6 Menghitung vektor V

Setelah nilai vektor $\mathrm{S}$ didapat, maka selanjutnya menjumlahkan seluruh vektor $\mathrm{S}$ untuk menghitung vektor $\mathrm{V}$.
$\mathrm{V} 1(\mathrm{~A}) \quad=\frac{S 1}{\Sigma S i}$
$=1,998925 / 20,76534=0,096263$
$\mathrm{V} 2(\mathrm{~B}) \quad=\frac{s 2}{\Sigma S i}$
$=1,850356 / 20,76534=0,089108$ 


$$
\begin{aligned}
& \mathrm{V} 3(\mathrm{C}) \quad=\frac{S 3}{\Sigma S i} \\
& =2,382786 / 20,76534=0,114748 \\
& \mathrm{~V} 4(\mathrm{D}) \quad=\frac{S 4}{\Sigma S i} \\
& =2,382786 / 20,76534=0,114748 \\
& \text { V5 (E) } \quad=\frac{S 5}{\Sigma S i} \\
& =1,870123 / 20,76534=0,09006 \\
& \mathrm{~V} 6(\mathrm{~F})=\frac{s 6}{\sum s i} \\
& =2,136484 / 20,76534=0,102887 \\
& \mathrm{~V} 7(\mathrm{G}) \quad=\frac{s 7}{\Sigma s i} \\
& =1,770403 / 20,76534=0,085258 \\
& \mathrm{~V} 8(\mathrm{H}) \quad=\frac{s 8}{\Sigma s i} \\
& =2,226734 / 20,76534=0,107233 \\
& \text { V9 (I) } \quad=\frac{s 9}{\Sigma s i} \\
& =2,276624 / 20,76534=0,109636 \\
& \mathrm{~V} 10(\mathrm{~J}) \quad=\frac{s 9}{\Sigma s i} \\
& =1,870123 / 20,76534=0,09006
\end{aligned}
$$

4.7 Perangkingan nilai

Setelah menghitung seluruh nilai vektor $\mathrm{V}$ maka selanjutnya dilakukan perangkingan untuk seluruh alternatif dari nilai terbesar hingga terkecil. Dari perangkingan tersebut diperoleh keputusan alternatif yang mendapat nilai tertinggi memiliki prioritas utama untuk mendapatkan dana bantuan sosial.

Sehingga jika masyarakat Jorong Batang Piarau mendapatkan bantuan sosial, maka untuk pendistribusiannya dapat diprioritaskan dari peringkat yang paling teratas sampai dengan yang paling bawah,sesuai dengan jumlah kuota bantuan sosial yang diterima.

Tabel 5. Hasil Akhir Setelah Dirangking

\begin{tabular}{|l|l|l|}
\hline Alternatif & Hasil & Rangking \\
\hline C & 0,114748 & 1 \\
D & 0,114748 & 2 \\
I & 0,109636 & 3 \\
H & 0,107233 & 4 \\
F & 0,102887 & 5 \\
A & 0,096263 & 6 \\
E & 0,09006 & 7 \\
J & 0,09006 & 8 \\
B & 0,089108 & 9 \\
G & 0,085258 & 10 \\
\hline
\end{tabular}

Tabel 5 di atas menunjukkan bahwa dari hasil proses perhitungan dengan metode weighted product menghasilkan keputusan yang memiliki prioritas utama penerima dana bantuan sosial adalah alternative $\mathrm{C}$ dan $\mathrm{D}$.

\section{KESIMPULAN DAN SARAN}

Penerapan metode weighted product terbukti dapat menghasilkan perangkingan penerima bantuan dana sosial bagi masyarakat yang terkena dampak pandemic covid 19 berdasarkan kriteria yang telah ditentukan oleh pihak penyalur. Ada lima kriteria yang ditetapkan yaitu status pekerjaan, status rumah, domisili, tanggungan dan pendapatan per bulan. Berdasarkan hasil penelitian ini, maka peneliti menyarankan beberapa hal untuk penelitian selanjutnya yaitu menggunakan metode pendukung keputusan yang lain dengan jumlah kriteria yang lebih banyak sehingga menghasilkan keputusan yang lebih optimal.

\section{DAFTAR PUSTAKA}

[1] R. Pakpahan and Y. Fitriani, "ANALISA PEMANFAATAN TEKNOLOGI INFORMASI DALAM PEMBELAJARAN JARAK JAUH DI TENGAH PANDEMI VIRUS CORONA COVID-19 Roida," JISAMAR (Journal Inf. Syst. Applied, Manag. Account. Researh, vol. 4, no. 2, pp. 30-36, 2020.

[2] J. G. Rizal, "Pandemi Covid-19, Apa Saja Dampak pada Sektor Ketenagakerjaan Indonesia?," Kompas.com, 2020. https://www.kompas.com/tren/read/2020/08/11/102500 165/pandemi-covid-19-apa-saja-dampak-pada-sektorketenagakerjaan-indonesia-?page $=$ all .

[3] N. Kusumawardhany, "Penerapan Metode Analytical Hierarchy Process (Ahp) Dan Simple Additive Weighting (Saw) Untuk Penentuan Penerima Bantuan Sosial Pandemi Covid-19," IDEALIS Indones. J. Inf. Syst., vol. 3, no. 2, pp. 56-60, 2020.

[4] K. Eliyen and F. S. Efendi, "Implementasi Metode Weighted Product Untuk Penentuan Mustahiq Zakat," InfoTekJar (Jurnal Nas. Inform. dan Teknol. Jaringan), vol. 4, no. 1, pp. 146-150, 2019, doi: 10.30743/infotekjar.v4i1.1476.

[5] S. Firdyana, D. Cahyadi, and I. F. Astuti, "Penerapan Metode Weighted Product untuk Menentukan Penerima Bantuan Beras Masyarakat Miskin (Raskin)," Pros. Semin. Ilmu Komput. dan Teknol. Inf., vol. 2, no. 1, pp. 336-342, 2017.

[6] A. R. Deny Wiria Nugraha, A.Y. Erwin Dodu, "Implementasi Algoritma Rsa Pada Sistem Pendukung Keputusan Pengalokasian Dana Bantuan Langsung Masyarakat Dengan Metode Weighted Product (Studi Kasus Desa Beka Kecamatan Marawola Kabupaten Sigi)," J. Ilmu Komput., vol. 12, no. 1, p. 16, 2019, doi: 10.24843/jik.2019.v12.i01.p01.

[7] D. P. Sari, "SPK SELEKSI PENERIMAAN GURU BARU PADA YAYASAN GARIS PENA PAYAKUMBUH MENGGUNAKAN METODE SAW Dian," J-Click, vol. 6, no. 2, pp. 201-207, 2019.

[8] Heny Pratiwi, Buku Ajar Sistem Pendukung Keputusan. Yogyakarta: deepublish, 2016.

[9] A. Noprin Pakaya, "SISTEM PENDUKUNG KEPUTUSAN PEMILIHAN PESERTA KAPAL PEMUDA NUSANTARA DENGAN MENGGUNAKAN METODE WEIGHTED PRODUCT (WP) Noprin," Ilk. J. Ilm., vol. 9, no. 3, pp. 331-337, 2017.

[10] R. wardoyo Sri Kusumadewi, sri hartati, agus harjoko, Fuzzy Multi-Attribute Decision Making. Yogyakarta: Graha Ilmu, 2006. 


\section{BIODATA PENULIS}

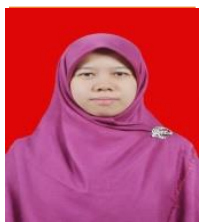

\section{Dian Permata Sari}

Dosen STMIK Jayanusa Padang.

Memperoleh gelar sarjana S1 di Universitas Putra Indonesia "YPTK" Padang dan S2 juga di tempat yang sama dengan bidang ilmu teknologi informasi 